\title{
Detecting Fraudulent Financial Reporting Using Fraud Score Model and Fraud Pentagon Theory: Empirical Study of Companies Listed in the L.Q. 45 Index
}

\author{
NAOMI CLARA SITUNGKIR \\ DEDIK NUR TRIYANTO \\ Telkom University, Indonesia
}

\begin{abstract}
Misstatements and concealment of facts about the value of accounts in the financial statements indicate a fraudulent financial reporting. As a result, financial information is irrelevant and misleading. The purpose of this study was to test the fraud pentagon theory in detecting fraudulent financial reporting using the fraud score model of companies listed in the L.Q. 45 index on the Indonesia Stock Exchange in 2014-2018. The results showed that fraud pentagon theory simultaneously affects the fraudulent financial reporting. Partially, financial stability and Family firms have a positive effect, external pressure and total accruals have a negative effect, and the nature of the industry, effective monitoring, changes in auditors, Change in director, the proportion of independent commissioners, and a frequent number of CEO's picture do not affect fraudulent financial reporting. Based on the results of the research, fraud pentagon theory can be used to minimize the occurrence of fraudulent financial reporting that may be done by the company by ensuring the fairness of a financial report and assessing the risk of fraud by taking into account all aspects, especially on asset change ratios, debt ratios, accounts receivable ratios, percentage of independent audit committees change in auditors, changes in directors.
\end{abstract}

Keywords: Fraud pentagon theory, Fraudulent financial reporting, Fraud score model.

Abstrak: Salah saji dan penyembunyian fakta yang disengaja terhadap nilai akun dalam laporan keuangan mengindikasikan adanya kecurangan pelaporan keuangan. Akibatnya, informasi keuangan tidak relevan dan menyesatkan. Tujuan penelitian ini adalah menguji teori fraud pentagon dalam mendeteksi kecurangan pelaporan keuangan menggunakan fraud score model pada perusahaan yang terdaftar dalam indeks LQ 45 di Bursa Efek Indonesia periode 2014-2018. Hasil penelitian menunjukkan teori fraud pentagon berpengaruh secara simultan terhadap fraudulent financial reporting. Secara parsial financial stability dan family firms berpengaruh secara positif, external pressure dan total accrual berpengaruh secara negatif, dan nature of industry, effective monitoring, change in auditor, change in director, proportion of independent commissioners, dan frequent number of CEO's picture tidak berpengaruh terhadap fraudulent financial reporting. Berdasarkan hasil penelitian, analisis fraud pentagon dapat digunakan untuk meminimalisir terjadinya fraudulent financial reporting yang mungkin dilakukan perusahaan dengan memastikan kewajaran atas suatu laporan keuangan dan menilai risiko fraud dengan

\footnotetext{
* Corresponding author: naomiclaraas@gmail.com
} 
memperhatikan seluruh aspek khususnya pada rasio perubahan aset, rasio utang, rasio piutang, persentase komite audit independen, pergantian akuntan publik, perubahan susunan direksi.

Kata Kunci: Teori kecurangan pentagon, kecurangan pelaporan keuangan, model skor kecurangan

\section{Introduction}

Fraud is an intentional illegal act that causes benefits for those who do it, and unwittingly gives harm to other parties. Financial reporting containing fraud is usually done by presenting misstatements relating to the amount, classification, presentation, and disclosure (Hery, 2016). Based on a survey conducted by the Association of Certified Fraud Examiners (2018), the types of fraud that occurred most during 2018 were included in the fraud tree category, namely the case of misappropriation asset by $89 \%$ and followed by corruption cases by $38 \%$ and cases of fraudulent financial reporting by $10 \%$. However, the type of fraud that has the most significant impact on financial losses is fraudulent financial reporting.

The theory put forward by Crowe Howard in 2011 states that the existence of fraudulent financial reporting is caused by pressure, opportunity, rationalization, competence, and arrogance; the five factors are fraud pentagon. This theory is a renewal theory of the fraud triangle theory and fraud diamond theory by developing factors that can lead a person to commit fraud (Gupta \& Kumar, 2020).

Cases of fraudulent financial reporting occurred at PT Hanson International Tbk (MYRX), which has successfully entered the L.Q. 45 Index list from 2016 to 2018. PT MYRX is considered to have manipulated because it did not disclose the binding purchase agreement in the 2016 annual report to sell the ready plot. PT MYRX violated the provisions of PSAK 44 on recognition of income using the full accrual method. From the case of PT MYRX, the factors causing fraudulent financial reporting include the factors pressure from external parties to present company performance that looks positive by manipulating sales in the financial statements. This is reinforced by the leverage ratio of PT MYRX from 2015-2018, which always experiences an increase. 
This leverage ratio is calculated by dividing total assets by total corporate debt, wherein 2015 PT MYRX's leverage ratio was $23.82 \%$, in 2016 an increase in the leverage ratio was $28.49 \%$, in 2017 there was an increase in a leverage ratio of $30.44 \%$, in 2018 an increase in the leverage ratio of $31.83 \%$. This indicates that the financial performance of PT MYRX is getting worse due to the higher obligations that must be paid, which makes the company committed fraud.

Another fraud case is the case of alleged window dressing of the 2018 financial statements by P.T. Bank Tabungan Negara (BTN) in the form of lending that is not by the provisions, to P.T. Perusahaan Pengelola Aset (PPA). From this case, it can be seen the factor opportunity that motivated the directors of PT BTN to minimize the company's bad credit by selling the receivables pattern. Then there is the ability factor that indicates an effort to improve the results of the previous directors' performance that allows for fraud committed.

Based on the fraud pentagon theory, fraudulent financial reporting can be caused by pressure applied to management; such pressure can be pressure from within the company and pressure from third parties (Achmad \& Pamungkas, 2018). Opportunities to commit financial reporting are caused by chance that management can exploit (Damayani, Wahyudi, \& Yuniartie, 2017). However, these opportunities can be minimized with effective monitoring (Puspasari, 2015). The rationalization factor triggers management to commit fraud and seek justification for these actions (Albrecht, Holland, Malagueño, Dolan, \& Tzafrir, 2015). The competence someone has in terms of position or position allows him to commit fraud (Aprilia, 2017). Then the arrogance factor can trigger fraud on the financial statements by utilizing the authority they have. The research results (Siddiq, Achyani, \& Zulfikar, 2017) and (N, Z, \& W, 2019) states that the fraud pentagon theory can be used to detect fraudulent financial reporting.

In detecting fraudulent reporting by companies listed in the L.Q. 45 Index, this study uses the F-score detection model proposed by (Dechow, Hutton, Kim, \& Sloan, 2012). The F-score model is considered more comprehensive in detecting fraudulent financial reporting. According to (Aghghaleh, Zakiah Muhammaddun Mohamed, \& Mohd Mohid Rahmat, 2016), F-score is better able to detect fraudulent financial 
reporting, which is also supported by research conducted by Hugo (2019), stated that the overall F-score could detect financial reporting fraud. F-score model has a positive value of fraud so that the greater the value of F-score owned by the company, the more likely the company is committing fraud (Hugo, 2019).

Based on the background explained, this study was conducted to review the fraud pentagon theory of fraudulent financial reporting on companies listed in the L.Q. 45 index. This study adds a new combination of proxies in measuring fraud pentagon factors. This study aims to examine and provide further clarification of whether the fraud pentagon theory can be used to detect financial reporting in particular for companies listed in the L.Q. 45 index during the 2014-2018 period. This research contributes to providing additional knowledge of the development of factors that influence companies to commit fraud in financial statements using pentagon fraud. Users of financial statements are expected to provide information on matters that can lead to financial statement fraud so they can be more careful in making decisions.

\section{Theoretical Framework and Hypothesis Development}

\subsection{Fraudulent Financial Reporting}

According to the Association of Certified Fraud Examiners (2018), fraudulent financial reporting is a misstatement of the truth that is not revealed or concealment of a material fact to harm others. Fraudulent financial reporting is worrying because it involves company management and causes the highest losses for investors. There are several financial reporting fraud schemes such as, alteration or manipulation of financial statements, deliberate material misstatement or misrepresentation of events, transactions, accounts, or other vital information used to prepare financial statements, deliberate misunderstandings such as mistakes in applying generally accepted accounting standards, principles, policies and methods used to measure reporting business transactions, deliberate misunderstandings in applying generally accepted accounting standards, principles, policies and methods used to measure reporting business transactions, and negligence in expressing or presenting disclosures that are not by accounting standards, intentionally (Albizri, Appelbaum, \& Rizzotto, 2019). 


\subsection{Fraud Pentagon Theory}

Three main fraud theories have been put forward, including the fraud triangle, fraud diamond, and fraud pentagon. The fraud triangle theory states that three factors can cause fraud: pressure, opportunity, and rationalization. In the fraud diamond theory added one factor that can cause fraud, namely the competence factor. Fraud pentagon theory is the latest fraud development theory developed by Crowe Howarth in 2011. In fraud pentagon theory, the fraud factor is added, namely, arrogance. Arrogance is a factor caused by fraud perpetrators overriding the company's policies and rules that apply because they feel they have a superior position (Gupta \& Kumar, 2020). According to Horwath (2011), a study conducted by the Committee of Sponsoring Organizations of the Treadway Commission (COSO) has found that $70 \%$ of fraud perpetrators have profiles that combine pressure with arrogance or greed, and $89 \%$ of fraud cases involve CEOs (Yusof, Khair, \& Simon, 2015).

\subsection{Prior Research and Hypothesis Development}

\subsubsection{Effects of Pressure, Opportunity, Rationalization, Competence, and Arrogance on Fraudulent Financial Reporting.}

The fraud pentagon theory proposed by Crowe Howarth in 2011 explains that pressure, opportunity, rationalization, ability, and arrogance are factors that influence fraud. The company's financial performance is an attraction for the stakeholders so that the declining condition of the company will cause a decline in the company's attractiveness.

Management's pressure to maintain the company's financial condition to look stable often causes management to commit fraud by manipulating the company's financial statements. In this study, the proxy for measuring pressure is represented by financial stability by measuring the company's total assets and external pressure by measuring the leverage ratio. The total value of assets owned by companies is often an attraction by investors and creditors. Management is often faced with pressure to manage the company's assets to make it look stable. Also, company management often experiences pressure to look competitive by seeking external financing sources or 
increasing debt, which is then used to finance research and development or capital expenditure. Companies with high levels of debt will put pressure on management because they must manage the company's financial performance and be able to pay company obligations.

The opportunity to commit fraud is exploited by management because of a weak control system. In this study, the proxy for measuring opportunity is represented by the industry's nature by measuring the bad debts of the company and effective monitoring by measuring the company's audit committee. Bad debts are one of the accounts whose management is estimated by the balance. Therefore the level of manipulation on bad debts is very high. The Audit Committee is responsible for supervising the company's financial reporting so that fraud can be prevented. Independence is an attitude that cannot be influenced.

Opportunities arising to commit fraud are often used as an excuse or justification for committing fraud. Rationalization is an essential factor in fraud because perpetrators of fraud are always looking for justification for their actions. Proxies used to measure rationalization in this study are auditor turnover and total accruals. The Change of auditor is one of the company's efforts to erase the audit trail found by the previous auditor. The ratio of total accruals can describe rationalization related to the use of accrual principles by management. The accrual basis in financial statements allows managers to modify financial statements because the accrual principle is related to decision making by management.

Management will try to cover up traces of fraud committed because the company has the ability. Proxies to measure ability in this study use the director's proxy change and the proportion of independent commissioners. The substitution of directors is the management's effort to cover up its fraud not to be detected by the directors. Changes in directors are considered capable of causing stress periods so that opportunities are more open to fraud. The board of commissioners is the culmination of a control system in large companies, which has a role in monitoring and certifying. Ideally, monitoring company performance will be more effective when more companies have an independent board of commissioners. Independent commissioners can minimize 
conflicts of interest because they will be objective in decision making and provide input if there is any indication of fraud to the company.

The arrogance of a leader drives him to commit acts of fraud and feels that his position cannot limit the actions taken. Proxies used to measure arrogance in this study are frequent numbers of CEO's picture and family firms. The number of CEO photos displayed in a company's annual report can represent the level of arrogance or superiority that the CEO has. Usually, someone who has a CEO position in the company wants to show the position he has. In Indonesia, many companies were initially a family company that has now gone public, so there are many cases in one company where the commissioner's position is owned by parents and their children become the company's managing director. Kinship owned by the two prominent positions in the company will lead to an indication of fraudulent behavior.

These five factors constitute fraud in financial reporting. Research conducted by Siddiq et al. (2017) states that the five factors in fraud pentagon have simultaneous and significant effects on fraudulent financial reporting. This is supported by research conducted by $\mathrm{N}$ et al. (2019), which states that fraud pentagon can be used to detect fraudulent financial reporting using secondary data because the measurement of all variables examined in the study uses secondary data in the form of audited financial statements that can be freely accessed by the public.

H1: Pressure, opportunity, rationalization, ability, and arrogance factors simultaneously affect the fraudulent financial reporting

\subsubsection{Effects of Pressure on Fraudulent Financial Reporting}

The pressure is one of the factors that can lead to fraud. If the perpetrators feel that they are experiencing pressure, this can lead them to commit fraud. The pressure felt by the perpetrators can arise from various conditions such as financial and non-financial conditions. Pressure often arises because of the achievement that must be met from an expectation imposed on investors for management. However, getting pressure should not be used as a basis for manipulating financial statements. Maintaining the condition of the company to remain stable is often pressure for management. SAS No. 99 
explained that managers encounter pressure when economic and industrial conditions threaten financial stability. If the perpetrators believed that they were pressurized, this belief could lead to fraud.

The company's financial condition, which is declared stable, can be measured through the growth of the company's total assets (Sasongko \& Wijayantika, 2019). When the total value of a company's assets is large, the company is considered to have operated well and can provide a large return to investors. However, the decline in the company's assets' total value can reduce the interest of stakeholders to invest in the company because the condition of the company is considered not operating properly and is not profitable. Percentage change in total assets can indicate fraud in the financial statements because a high percentage change in total assets can indicate a company's earnings performance and strong financial position. Research conducted by Skousen et al. (2009) proves that the higher the ratio of changes in a company's total assets, the indication of fraudulent actions against the company's financial statements is higher.

This study predicts that financial stability has a positive effect on fraud in financial reporting. The prediction of positive influence refers to the results of research conducted by Apriliana \& Agustina (2017) and Annisya et al. (2016), which states that the pressure factor in the form of financial stability with a proxy for the ratio of asset growth has a positive effect against fraudulent financial reporting. Rapid asset growth positively influences the occurrence of fraudulent financial reporting. Therefore, the following hypothesis is formulated in this study:

\section{H2: Financial stability partially has a positive effect on fraudulent financial reporting}

External pressure is a proxy for measuring pressure factors by using leverage ratios to determine the size of the company's debt balance (Sasongko \& Wijayantika, 2019). When a company has a high level of leverage ratio, its credit risk is even greater. These conditions are taken into consideration for creditors in providing loans to companies. If the company does not get additional financing, there will be pressure for management to commit fraudulent financial reporting to display positive financial performance. Also, companies with high levels of debt will put pressure on management because they must manage the company's financial performance and be able to pay company 
obligations. Creditors will evaluate the company's ability to pay its obligations; if the company's ability to meet its obligations is bad, it will affect the opportunity to get a loan going forward. Because of these pressure factors, the company's management will try to manipulate its financial statements.

This study predicts that external pressure positively influences financial reporting fraud. The prediction of positive influence refers to Tiffani's (2015) research and Yesiariani \& Rahayu (2017), which states that the pressure factor in the form of external pressure with a proxy leverage ratio has a positive effect on fraudulent financial reporting. Companies that have high leverage ratios are considered to have large debts and face high credit risk. The emergence of large debts often causes management to report high profits, so it is not uncommon for companies to commit financial reporting fraud by increasing the profits they obtain. Therefore, the following hypothesis is formulated in this study:

H3: External pressure, partially has a positive effect on fraudulent financial reporting

\subsubsection{Effects of Opportunity on Fraudulent Financial Reporting.}

Opportunity is a situation that allows fraud to be carried out. Someone who considers an opportunity to commit fraud usually feels that he will not do it if caught, or there is no way fraud can be proven. The knowledge developed by perpetrators of fraud in their professional fields makes it possible to exploit and create fraud opportunities. According to the SAS No.99 nature of the industry provides an opportunity for management to engage in financial reporting fraud due to subjective judgments in estimating an account, and it is difficult to ascertain it. The nature of the industry is an ideal condition of a company in an industry.

The increasing condition of the company's receivables can indicate fraudulent practices by the company. The increase in accounts receivable balances is done by manipulating the bad debts account. Bad debts are the main focus of management who will commit financial reporting fraud because it is estimated based on management subjectivity assessment. 
This study predicts that the nature of the industry has a positive effect on fraud in financial reporting. The prediction of positive effects refers to the results of research conducted by Muhandisah \& Anisykurlillah (2016) and Damayani et al. (2017), which states that the opportunity factor in the form of the nature of the industry with a proxy for the ratio change of receivables has a positive effect on fraudulent financial reporting. Therefore, the following hypothesis is formulated in this study:

H4: Nature of Industry, partially has a positive effect on fraudulent financial reporting

Fraudsters will take advantage of opportunities by planning strategies and understanding the system. Knowing provides the ability to manipulate and disconnect internal controls by avoiding detection. A good oversight mechanism is one way that can be done to minimize fraudulent financial reporting. An independent audit committee is believed to be able to increase the effectiveness of supervision. This independence aims to improve the report's integrity and objective views because independent individuals tend to be more just and impartial and objective in handling problems that arise in management. Based on the Financial Services Authority Regulation No. 55 / POJK.04 / 2015 concerning the Formation and Guidelines for the Work of Audit Committee article 4, it is stated that the audit committee consists of at least 3 (three) members who are from Independent Commissioners and Parties outside Issuers or Public Companies. An independent audit committee does not have an important position in the company and does not have a conflict of interest with the company. Companies that want to increase the quality and trustworthiness of financial statements and good corporate governance tend to increase their audit committee (Hussain Alkdai \& Hanefah, 2012). However, an independent audit committee is more capable of increasing the effectiveness of supervision of the opportunistic attitudes that management will undertake and is more proven to provide good governance.

This study predicts that effective monitoring negatively influences fraudulent financial reporting. The prediction of the negative influence refers to Tiffani's (2015) research and Ratmono et al. (2017), which states that the opportunity factor in the form of effective monitoring has a negative effect on fraudulent financial reporting. Therefore, the following hypothesis is formulated in this study: 
H5: Effective Monitoring partially has a negative effect on fraudulent financial reporting

\subsubsection{Effects of Rationalization on Fraudulent Financial Reporting.}

Rationalization is a reason used to justify fraud and consider it a reasonable action to do. Rationalization can be proxied by auditors' changes because fraud companies tend to replace their external auditors to cover up fraud committed by management (Siddiq et al., 2017). The company considers that the previous auditor will be faster to detect any possibility of fraud committed by management, both directly and indirectly. Also, the Change of auditors will increase audit failures, making fraudulent practices of companies challenging to detect (Stice, 1991).

The company can replace its external auditors based on established regulations or voluntarily to improve audit quality, financial difficulties, and various other reasons. However, if the company frequently changes auditors, it can indicate that the company is trying to cover up its fraudulent practices. Changes in auditors in this study did not consider whether changes were made mandatory or voluntary.

This study predicts that Change in auditor has a positive effect on fraud in financial reporting. The prediction of positive influence refers to the research results conducted by Saputra \& Kesumanignrum (2015) and Siddiq et al. (2017) research, which states that the rationalization factor is proxied by a change in auditor has a positive effect on reporting fraud finance. Change in auditor is a form of management's effort in eliminating the trail of fraud detected by the previous auditor, and management will continue to commit fraud as long as the external auditor is not aware of it. Therefore, the following hypothesis is formulated in this study:

\section{H6: Change in Auditor partially has a positive effect on fraudulent financial reporting}

The accrual principle provides insight into rationalization in financial reporting. This study predicts that total accruals have a positive effect on financial reporting fraud. Prediction of positive influence refers to the results of research conducted by Muhandisah \& Anisykurlillah (2016), which states that rationalization, which is proxied by total accruals, has a positive and significant effect. This is because total accruals 
represent a description of the company's overall activities and believe that accruals can represent management in decision-making and provide insights on the rationalization of the company's financial statements. Supported by the results of research conducted by Yesiariani \& Rahayu (2017) and Murtanto \& Iqbal Muhammad (2016), total accruals positively affect financial reporting fraud. Therefore, rationalization, which is proxied by total accruals, positively affects fraudulent financial reporting. Therefore, the following hypothesis is formulated in this study:

H7: Total Accrual partially has a positive effect on fraudulent financial reporting

\subsubsection{Effects of Capability on Fraudulent Financial Reporting.}

The capability is seen from one's expertise in committing fraud and the position of someone who commits fraud in the company (Yendrawati, Aulia, \& Prabowo, 2019). According to Apriliana \& Agustina (2017), directors' changes are considered capable of causing stress periods so that opportunities for fraud are increasingly open. Director's policies can affect the results of financial statements, which can be bad or even manipulate. Based on the research results, Sasongko \& Wijayantika (2019) states that the capability proxied by the Change of directors influences fraud. This study predicts that the Change of directors has a positive effect on fraudulent financial reporting. Prediction of positive influence refers to the results of Saputra \& Kesumanignrum (2015) and Triyanto (2019), which states that the Change of directors has a positive and significant effect. Change of directors is one of the company's efforts to eliminate directors who are considered aware of fraud by the company, and changes in directors are considered to reduce the effectiveness of company performance due to cultural changes implemented by new directors that require a long time to adapt. Therefore, the capability proxied by the Change of directors has a positive effect on fraudulent financial reporting. Therefore, the following hypothesis is formulated in this study:

H8: Change of Director partially has a positive effect on fraudulent financial reporting

Circumstances that make fraud possible can be caused by a large number of nonindependent boards of commissioners. A large number of an independent board of commissioners can illustrate the ability to minimize fraud practices because the 
independent board of commissioners is tasked with overseeing and evaluating the company's operational performance. The more the number of independent boards of commissioners, the more able to minimize companies' opportunistic behavior that can indicate fraud. According to Yendrawati et al. (2019), ideally, monitoring company performance will be more effective when more companies have an independent board of commissioners.

This study predicts that the proportion of the board of commissioners negatively affects financial reporting fraud. The prediction of negative influence refers to the results of Indarto \&Ghozali (2016) research, which states that the ability that is proxied by the proportion of independent commissioners has a negative and significant effect. That is because independent commissioners can minimize conflicts of interest. Research conducted by Dahya \& McConnell (2005) concludes that the higher the presentation of independent directors can provide good decisions and discipline management to avoid fraud practices; this states that the proportion of independent commissioners negatively affects financial reporting fraud. After all, independent commissioners will be objective in decision making and provide an opinion if there is any indication of fraud to the company. Therefore, the following hypothesis is formulated in this study:

H9: Proportion of Independent Commissioners partially has a negative effect on fraudulent financial reporting

\subsubsection{Effects of Arrogance on Fraudulent Financial Reporting.}

The number of CEO photos displayed in a company's annual report can represent the level of arrogance or superiority that the CEO has (Sasongko \& Wijayantika, 2019). The frequent number of CEO's pictures is the number of depictions of a CEO in a company by displaying profiles, achievements, photographs, or other information regarding the CEO's track of the record, which is presented repeatedly in the company's annual report (Siddiq et al., 2017). This study predicts that frequent numbers of CEO's pictures have a positive effect on financial reporting fraud. Prediction of positive influence refers to Tessa \& Harto (2016) research and Bawakes et al. (2018), which 
states that the frequent number of CEO's pictures has a positive and significant effect. A high level of arrogance can lead to fraud because of a CEO's arrogance and superiority, making him feel that any internal control will not apply to him because of the status and position he has and will do whatever means to maintain the position and position he currently has. Therefore, the ability proxied by a frequent number of CEO pictures positively affects fraudulent financial reporting. Therefore, the following hypothesis is formulated in this study:

H10: Frequent number of CEO's pictures partially has a positive effect on fraudulent financial reporting

The number of initially family companies and has now gone public made the board of directors and the board of commissioners often concerning family relations. So there are many cases in one company where the commissioner's position is owned by parents and their children become the main director in the company. The kinship that is owned by two main positions in the company will indicate fraud behavior. The board of commissioners whose function is to supervise and the board of directors whose function is to manage and be responsible for its operational activities. Family firms can supervise the directors' performance less effective, and directors will be freer to commit fraud.

This study predicts that Family firms have a positive effect on financial reporting fraud. Prediction of positive influence refers to the results of research conducted by Chi et al. (2015), who states that the arrogance proxied by Family firms has a positive and significant effect. This is because the CEO cannot conduct the chairman of a monitoring function separate from his interests, and such situations can lead to financial fraud. Research conducted by Matoussi \& Gharbi (2011) also concluded that family firms influence increasing the probability of fraud practices, the existence of directors and commissioners who have family relationships that provide the power to dominate in making decisions.

Therefore, the arrogance proxied by Family firms has a positive effect on fraudulent financial reporting. Therefore, the following hypothesis is formulated in this study:

H11: Family firms partially has a positive effect on fraudulent financial reporting 
Figure 1.

Research design

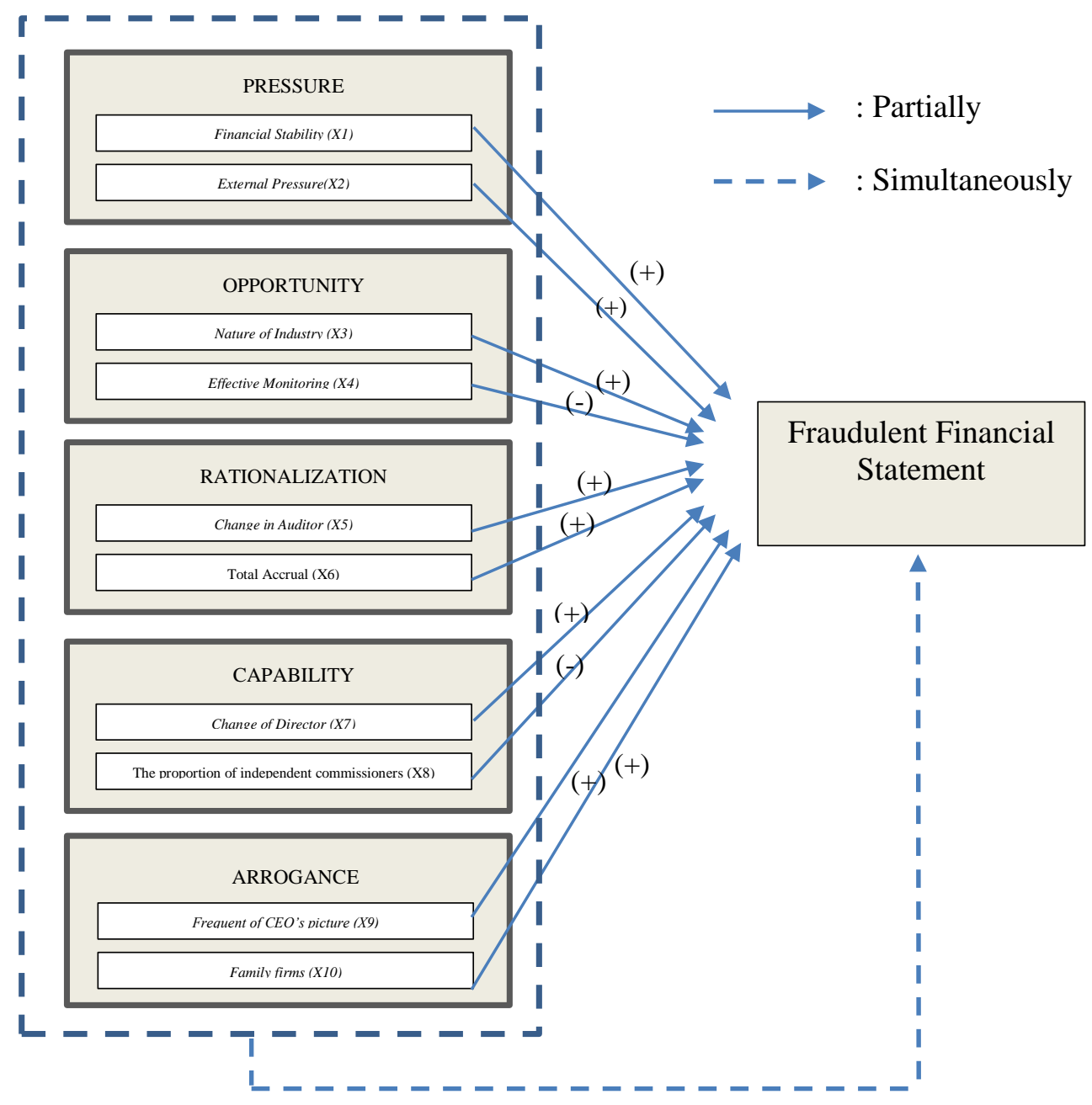

\section{Research Method}

This study was conducted to explain the characteristics of the pentagon fraud variable and fraudulent financial reporting, which is based on several phenomena of proven fraud. Quantitative research methods are used in this study using secondary data. This study uses secondary data in the form of company financial statements with data collection methods through the Indonesia Stock Exchange's official website. 
This study examines the factors that influence fraudulent financial reporting actions. The dependent variable in this study is fraudulent financial reporting, which is proxied by an F-score model. There are two indicator variables in the F-score formula, including accrual quality and financial performance, which can be used to detect fraud indications. The independent variable used is the fraud pentagon theory, which consists of pressure, opportunity, rationalization, capability, and arrogance.

Pressure proxied by financial stability (ACHANGE) to see the pressure that can arise by maintaining the company's financial stability based on the value of its assets, and external pressure (LEV) to measure the pressure factor by using a leverage ratio to find out the amount of the debt balance used to finance the company's operations. Opportunity proxied by nature of the industry (N.I.) to determine the allowance for uncollectible receivables and effective monitoring (IND) by using an independent audit committee that is responsible for the effectiveness of financial statement accrual (TATA) to describe rationalization related to the use of the accrual principle by management. Capability proxied by Change of director (DCHANGE), and proportion of independent commissioners (BDOUT). Arrogance proxied by a frequent number of CEO's picture (CEOPIC) by counting the number of CEO photos and other information about the CEO track record that is repeatedly described in the company's annual report, and family firms (DUAL) to find out if there is a kinship between the CEO and the commissioner who has power dominance.

This research is included in quantitative research so that the data analysis techniques used in this study are descriptive statistical analysis and logistic regression analysis.

The model equation in this study is described as follows:

$$
\begin{gathered}
\operatorname{Ln} \frac{\text { Fraud }}{1-\text { Fraud }}=-\beta_{0}+\beta_{1} \text { ACHANGE }-\beta_{2} \text { LEV }+\beta_{3} \text { NI }-\beta_{4} \text { IND }-\beta_{5} \text { AUDCHANGE }-\beta_{6} \text { TATA }-\beta_{7} \text { DCHANGE } \\
-\beta_{8} \text { BDOUT }+\beta_{9} \text { CEOPIC }+\beta_{10} \text { DUAL }
\end{gathered}
$$


Or if it is downgraded to:

FRAUD $=\frac{1}{1+\mathrm{e}^{-\left(-\beta_{0}+\beta_{1} \text { ACHANGE }-\beta_{2} \text { LEV }+\beta_{3} \text { NI }-\beta_{4} \text { IND }-\beta_{5} \text { AUDCHANGE }-\beta_{6} \text { TATA }-\beta_{7} \text { DCHANGE }-\beta_{8} \text { BDOUT }+\beta_{9} \text { CEOPIC }+\beta_{10} \text { DUAL }\right)}}$

Notes :

Fraud

$=$ Fraudulent Financial Reporting

Ln

= Natural logarithm

E

$=$ Base on Natural Logarithm values

$\beta_{0}$

$=$ Constant regression coefficient

$\beta_{1,} \beta_{2,} \beta_{3,}, \beta_{4,} \beta_{5,} \beta_{6,} \beta_{7}, \beta_{8}, \beta_{9,} \beta_{10}$

$=$ Regression coefficient of each variable

FS

$=$ Financial Stability

LEV

$=$ External Pressure

NI

$=$ Nature of Industry

E.F. = Effective Monitoring

CPA

TATA

DCHANGE

IND

CEOPIC

DUAL

$$
\begin{aligned}
& =\text { Change of Auditor } \\
& =\text { Total Accrual } \\
& =\text { Change of director } \\
& =\text { proportion of independent commissioners } \\
& =\text { Frequent Number of CEO's Picture } \\
& =\text { Family firms }
\end{aligned}
$$

Testing the hypothesis in this study was carried out in several stages, starting with the logistic regression model's feasibility assessment using the Hosmer and Lemeshow's Goodness of Fit Test, the overall fit model, and the coefficient of determination. The significance test of the Fraud Pentagon variable and the Fraudulent Financial Reporting variable can be done using a simultaneous test. The $\mathrm{F}$ statistical test aims to simultaneously test the significance of all independent variables on the study's dependent variable. Tests were performed using the Chi-square omnibus tests of model coefficients. A T-test or partial test is a hypothesis test in the logistic regression model using the Wald test value. The basis for decision making in conducting hypothesis 
testing uses the F statistical test and the T-test. If the significance value of $F>0.05$, it can be recognized that the test results have a simultaneous influence on the dependent variable. If the significance value of $\mathrm{T}>0.05$, it can be recognized that the independent variable has a partial effect on the dependent variable.

The population in this study is the companies included in the L.Q. 45 index list. The sample selection technique used is purposive sampling so that 17 companies are obtained with a study period of 5 years so that the total sample used is 85 . This study's sample selection is based on the following criteria: (1) Public companies listed on the Indonesia Stock Exchange and consistently included in the L.Q. 45 index in 20142018. (2) Public companies included in the L.Q. 45 index on the Indonesia Stock Exchange, which has complete data needed for research in 2014-2018. The operational definition of the variables is presented in Table 1.

Table 1.

Operational Variables

\begin{tabular}{|c|c|}
\hline Variables & Definition \\
\hline $\begin{array}{l}\text { Fraudulent } \\
\text { Financial } \\
\text { Reporting }\end{array}$ & $\begin{array}{l}\text { Fraudulent financial reporting in this study was detected using the F-score } \\
\text { measurement model developed by Dechow et al. (2012). The F-score model } \\
\text { was calculated using the following formula. } \\
\text { F-score = Accrual quality + Financial performance } \\
\text { According to Annisya et al. (2016), accrual quality was calculated using the } \\
\text { RSST accrual formula. } \\
\qquad \text { RSST Accrual }=\frac{\Delta W C+\Delta N C O+\Delta F I N}{\text { Average Total Assets }} \\
\text { The financial performance can be calculated with the following formula. } \\
\qquad \text { F.P. }=\quad+\text { Change on receivable }+ \text { Change on inventories } \\
\text { The F-Score value is identified using a dummy variable by giving code }+ \text { Change on earnings } \\
1 \text { to companies that are considered indicated committing financial reporting }\end{array}$ \\
\hline
\end{tabular}




\begin{tabular}{|c|c|}
\hline & $\begin{array}{l}\text { fraud if F-score }>1.00 \text { and code } 0 \text { against companies that are considered not } \\
\text { indicated to commit financial reporting fraud if F-score }<1.00 \text {. }\end{array}$ \\
\hline $\begin{array}{l}\text { Financial } \\
\text { Stability }\end{array}$ & $\begin{array}{l}\text { Financial stability is a picture of the condition of a company's stability from } \\
\text { a financial perspective. Financial stability proxy can be measured using the } \\
\text { formula described in Apriliana and Agustina, (2017) research as follows: } \\
\text { Financial stability }=\frac{\text { Total Aset }_{t}-\text { Total Aset }_{t-1}}{\text { Total Aset }_{t-1}}\end{array}$ \\
\hline $\begin{array}{l}\text { External } \\
\text { Pressure }\end{array}$ & $\begin{array}{l}\text { External pressure is a proxy to measure the pressure factor by using a } \\
\text { leverage ratio. The formula for calculating leverage ratios. } \\
\text { LEV }=\frac{\text { Total Liabilities }}{\text { Total Assets }}\end{array}$ \\
\hline $\begin{array}{l}\text { Nature of } \\
\text { Industry }\end{array}$ & $\begin{array}{l}\text { The nature of the industry is a method that can be used to determine the } \\
\text { allowance for uncollectible receivables (Umarsono, 2016). The Nature of } \\
\text { Industry proxy is calculated using the formula described in the research of } \\
\text { Damayani et al. (2017) as follows: } \\
\qquad \mathrm{NI}=\frac{\text { Receivable }_{\mathrm{t}}}{\text { Sales }_{\mathrm{t}}}-\frac{\text { Receivable }_{\mathrm{t}-1}}{\text { Sales }_{\mathrm{t}-1}}\end{array}$ \\
\hline $\begin{array}{l}\text { Effective } \\
\text { Monitoring }\end{array}$ & $\begin{array}{l}\text { Effective monitoring proxy is calculated using the formula described in } \\
\text { the research of (Tiffani 2015) as follows: } \\
\text { Effective Monitoring }=\frac{\text { Number of Independent Audit Committee Members }}{\text { Total Number of Audit Committees }}\end{array}$ \\
\hline $\begin{array}{l}\text { Change of } \\
\text { Auditor }\end{array}$ & $\begin{array}{l}\text { Change of Auditor proxies is calculated using the dummy variable by } \\
\text { giving code } 1 \text { for companies that change auditors and code } 0 \text { for companies } \\
\text { that do not change auditors. }\end{array}$ \\
\hline Total Accrual & $\begin{array}{l}\text { The ratio of total accruals can be used to describe rationalization } \\
\text { related to the accrual principle by management. Based on research by } \\
\text { Murtanto and Iqbal Muhammad (2016), the ratio of total accruals can be } \\
\text { calculated using the formula: } \\
\qquad \text { TATA }=\frac{\text { Total Accrual }}{\text { Total Asset }}\end{array}$ \\
\hline
\end{tabular}




\begin{tabular}{|l|l|}
\hline $\begin{array}{l}\text { Change of } \\
\text { Director }\end{array}$ & $\begin{array}{l}\text { Changes of directors are measured using a dummy variable by giving code } \\
1 \text { if there is a change of directors at the company and code } 0 \text { if there is no } \\
\text { change in directors }\end{array}$ \\
\hline $\begin{array}{l}\text { The proportion } \\
\text { of Independent } \\
\text { Commissioners }\end{array}$ & $\begin{array}{l}\text { Proxies of the proportion of independent commissioners can be } \\
\text { calculated using the formula as follows: } \\
\text { BDOUT = The number of independent commissioner }\end{array}$ \\
\hline $\begin{array}{l}\text { Frequent } \\
\text { number of } \\
\text { CEO's Picture }\end{array}$ & $\begin{array}{l}\text { the frequent number of CEOs can be measured using the total CEO } \\
\text { photos displayed in the company's annual report }\end{array}$ \\
\hline Family firms & $\begin{array}{l}\text { Family firms are measured using a dummy variable by giving code } 1 \text { if } \\
\text { there is a kinship between the CEO and the commissioner who has power } \\
\text { dominance and code } 0 \text { if not. }\end{array}$ \\
\hline
\end{tabular}

\section{Results and Discussion}

\subsection{Descriptive data}

Descriptive analysis of the variables used in this study can be divided into two based on the ratio and nominal scale as follows:

1. Descriptive analysis for variables with ratio scale is financial stability (ACHANGE), external pressure (LEV), nature of the industry (N.I.), effective monitoring (IND), total accrual (TATA), proportion of independent commissioners (BDOUT). Descriptive analysis for these variables is explained using minimum, maximum, mean, and standard deviation values. The results of the descriptive statistical tests are as follows: 
Tabel 2

Descriptive Statistics of Ratio Scale Test Results

\begin{tabular}{|l|r|r|r|r|r|}
\hline \multicolumn{1}{|c|}{ Variable } & \multicolumn{1}{c|}{$\mathrm{N}$} & \multicolumn{1}{c|}{ Minimum } & Maximum & \multicolumn{1}{c|}{ Mean } & \multicolumn{1}{c|}{ Std. Deviation } \\
\hline ACHANGE & 85 & .41 & 1.14 & .8724 & .12040 \\
\hline LEV & 85 & .13 & .84 & .4644 & .18366 \\
\hline N.I. & 85 & -11.66 & 5.16 & -.0165 & 1.51806 \\
\hline IND & 85 & .67 & 1.00 & .9892 & .05109 \\
\hline TATA & 85 & -.13 & .16 & .0102 & .04677 \\
\hline BDOUT & 85 & .17 & .83 & .3921 & .12334 \\
\hline CEOPIC & 85 & 2.00 & 9.00 & 4.3059 & 1.74590 \\
\hline
\end{tabular}

Source: Processed data

2. Descriptive analysis for variables with nominal scale, namely fraudulent financial reporting (FSCORE), Change of auditor (AUDCHANGE), Change of the director (DCHANGE), Family firms (DUAL). The results of the descriptive statistical tests are as follows:

Tabel 3

Descriptive Statistic Test Results for Nominal Scale

\begin{tabular}{|l|c|c|c|c|c|c|c|c|}
\hline \multirow{2}{*}{ Variable } & \multicolumn{4}{|c|}{ Valid 0 } & \multicolumn{4}{c|}{ Valid 1 } \\
\cline { 2 - 10 } & Frequency & $\%$ & $\begin{array}{c}\text { Valid } \\
\%\end{array}$ & $\begin{array}{c}\text { Cum. } \\
\%\end{array}$ & $\begin{array}{c}\text { Frequenc } \\
\text { y }\end{array}$ & $\%$ & $\begin{array}{c}\text { Valid } \\
\%\end{array}$ & $\begin{array}{c}\text { Cum. } \\
\%\end{array}$ \\
\hline FSCORE & 77 & 90.6 & 90.6 & 90.6 & 8 & 9.4 & 9.4 & 100 \\
\hline AUDCHANGE & 44 & 51.8 & 51.8 & 51.8 & 41 & 48.2 & 48.2 & 100 \\
\hline DCHANGE & 27 & 31.8 & 31.8 & 31.8 & 58 & 68.2 & 68.2 & 100 \\
\hline DUAL & 67 & 78.8 & 78.8 & 78.8 & 18 & 21.2 & 21.2 & 100 \\
\hline
\end{tabular}

Source: Processed data

Based on table 2, it can be seen that the companies listed in the L.Q. 45 Index on the Indonesia Stock Exchange in the 2014-2018 period of 9.4\% indicated fraudulent financial reporting while $90.6 \%$ were included in the category of not indicated fraudulent financial reporting. Companies that have indicated fraud will have a negative impact on companies that can reduce the company's image among stakeholders. If the company has ever committed fraud, it will likely continue because the fraudulent financial reporting is done to cover up its poor performance. This can only be stopped if an inspection is carried out. 
It is known that $48.2 \%$ of the sample of selected companies made changes in auditors (AUDCHANGE) during the 2014-2018 period, while 51.8\% did not make changes. Thus it can be seen in the company research period that the L.Q. 45 index does not change auditors too often.

It is known that $68.2 \%$ of the sample of selected companies made changes to the composition of the directors (DCHANGE) during the 2014-2018 period, while 31.8\% did not make changes to the composition of the directors of the company. Thus it can be seen that the sample company L.Q. 45 index during the study period often changes directors; this shows that there tends to indicate fraud.

It can be seen that $21.2 \%$ of the sample companies selected had Family firms (DUAL) during the 2014-2018 period, while $78.8 \%$ did not have Family firms. The number of initially a family company and has now gone public made the board of directors and the board of commissioners often concerning family relations.

\subsection{Logistic Regression Analysis}

\subsubsection{The goodness of Fit Test}

The feasibility of the regression model was assessed by Hosmer and Lemeshow's Goodness of Fit Test. Hosmer and Lemeshow's Goodness of Fit Test using the feasibility test can be seen in the following table:

Tabel 4

Hosmer and Lemeshow Test

\begin{tabular}{|c|c|c|c|}
\hline Step & Chi-square & df & Sig. \\
\hline 1 & 1.610 & 7 & .978 \\
\hline
\end{tabular}

Source: Processed data

Based on Table 3, it can be seen that the statistical value of the Hosmer and Lemeshow Test is 1.610 at a significant level of 0.978 , with a value of more than 0.05 . So it can be concluded that the model can be accepted because it follows the observation data used. 


\subsubsection{Overall Model Fit}

The next step in the logistic regression test is to assess the overall model (Overall Model Fit) by conducting a likelihood ratio test by comparing the initial -2Log Likelihood values (Block Number 0) with the final -2Log Likelihood (Block Number 1). If the $-2 \log$ Likelihood initial (Block Number 0) has a value greater than the $-2 \log$ Likelihood late (Block Number 1) means it shows a good regression model. -2Log Likelihood Value can be shown in the following table:

Tabel 5

Overall Model Fit Test

\begin{tabular}{|l|l|}
\hline -2Log Likelihood start (Block Number 0) & 56.574 \\
\hline -2 Log Likelihood end (Block Number 1) & 48.216 \\
\hline
\end{tabular}

Source: Processed data

In table 4 , it is known that the initial value of $-2 \operatorname{LogL}$ (Block Number 0) decreased by 56.574 with the final $-2 \operatorname{LogL}$ value (Block Number 1) of 48.216, indicating that the model hypothesized was fit with the data.

\subsubsection{Nagelkerke R Square}

The determination coefficient is the next step taken to find out how much the independent variable can affect the dependent variable using Nagelkerke R Square. The coefficient of determination determined based on Nagelkerke R Square values can be seen in the following table:

Tabel 6

Nagelkerke R Square

\begin{tabular}{|l|r|}
\hline \multicolumn{2}{|c|}{ Model Summary } \\
\hline Step & Nagelkerke R Square \\
\hline 1 & .660 \\
\hline
\end{tabular}

Source: Processed data

Based on data processing using logistic regression, obtained Nagelkerke R Square value of 0.660 . This can be interpreted that the fraud pentagon theory independent variables consisting of financial stability, external pressure, nature of the industry, effective monitoring, Change of auditors, total accruals, Change of directors, proportion 
of independent commissioners, frequent numbers of CEO's picture, and family firms in this study can explain the dependent variable fraudulent financial reporting by $66 \%$. In comparison, $34 \%$ detection of fraudulent financial reporting is explained by factors outside the variables used in this study.

\subsection{Hypothesis testing}

\subsubsection{Hypothesis testing simultaneously}

A simultaneous hypothesis test is conducted to determine the independent variables' effect on the dependent variable together (simultaneously). Testing the hypothesis in this study using a logistic regression model with a significance level of $0.05(5 \%)$. The test results can be seen in the Omnibus of Model Coefficients table, which shows significant results. The following are the results of the omnibus tests:

Tabel 7

Omnibus Tests of Model Coefficients

\begin{tabular}{|l|l|r|r|r|}
\hline \multicolumn{2}{|c|}{} & \multicolumn{1}{|c|}{ Chi-square } & \multicolumn{1}{c|}{ df } & \multicolumn{1}{c|}{ Sig. } \\
\hline \multirow{3}{*}{ Step 1 } & Step & 31.084 & 10 & .001 \\
\cline { 2 - 5 } & Block & 31.084 & 10 & .001 \\
\cline { 2 - 6 } & Model & 31.084 & 10 & .001 \\
\hline
\end{tabular}

Source: Processed data

Based on Table 6, it can be seen that the Chi-square value is 31.084 , and the significance value is 0.001 . The significance value is smaller than 0.05 . This shows that fraud pentagon variable consisting of financial stability, external pressure, nature of the industry, effective monitoring, Change of auditors, total accruals, Change of directors, proportion of independent commissioners, frequent numbers of CEO's picture, and family firms simultaneously influential in predicting fraudulent financial reporting.

\subsubsection{Partial Hypothesis Test}

Partial hypothesis testing in this study was conducted to determine each independent variable's relationship to the dependent variable. This test uses logistic 
regression with the method of the significance level of 0.05 . The following table results from partial testing:

Table 8

Partial Test (T-test)

\begin{tabular}{|l|l|r|r|r|}
\hline \multicolumn{5}{|c|}{ Variables in the Equation } \\
\hline \multirow{3}{*}{ Step $1^{\mathrm{a}}$} & ACHANGE & \multicolumn{1}{c|}{ B } & \multicolumn{1}{c|}{ S.E. } & \multicolumn{1}{c|}{ Sig. } \\
\cline { 2 - 5 } & LEV & -22.858 & 14.487 & .038 \\
\cline { 2 - 5 } & N.I. & .258 & 9.055 & .012 \\
\cline { 2 - 5 } & IND & 77.896 & .658 & .695 \\
\cline { 2 - 5 } & AUDCHANGE & -1.850 & 1.513 & .221 \\
\cline { 2 - 5 } & TATA & -58.589 & 24.335 & .016 \\
\cline { 2 - 5 } & DCHANGE & -1.070 & 1.566 & .494 \\
\cline { 2 - 5 } & BDOUT & -2.154 & 7.033 & .759 \\
\cline { 2 - 5 } & CEOPIC & .590 & .463 & .202 \\
\cline { 2 - 5 } & DUAL & 7.404 & 3.217 & .021 \\
\cline { 2 - 5 } & Constant & -104.590 & 78284.384 & .999 \\
\hline
\end{tabular}

Source: Processed data

Partial hypothesis testing in this study was conducted to determine each independent variable's relationship to the dependent variable. This test uses logistic regression with a method between the 0.05 significance level to determine the effect of each fraud pentagon consisting of financial stability, external pressure, nature of the industry, effective monitoring, Change of auditors, total accruals, Change of directors, proportion of independent commissioners, frequent numbers of CEO's picture, and family firms on fraudulent financial reporting.

The logistic regression test results on the pressure variable with the ACHANGE ratio indicator show a regression coefficient value of 32.562 and a probability value (sig.) Of 0.038 , where the value of sig. smaller than $0.05(\alpha=5 \%)$. So in this study, the hypothesis was accepted. While the pressure variable measured using the leverage (LEV) ratio indicator shows the probability value (sig.) Of 0.012 , where the value of sig. smaller than $0.05(\alpha=5 \%)$. However, this study's regression coefficient value showed a negative result of -23.370 , which means that the pressure variable, which is 
proxied by external pressure (LEV), has a significant negative effect on financial reporting fraud in this study, the hypothesis was rejected.

Logistic regression test results on the opportunity variable with the indicator ratio of the nature of the industry (N.I.) showed a coefficient value of 0.761 and a probability value (sig.) Of 0.447 , where the value of sig. greater than $0.05(\alpha=5 \%)$. The study results concluded that the opportunity variable proxied by the nature of the industry (N.I.) partially did not affect fraudulent financial reporting, so in this study, the hypothesis was rejected. The opportunity variable with an effective monitoring ratio indicator (IND) shows a coefficient value of -30.264 and a probability value (sig.) of 0.383 , where a value of sig. greater than $0.05(\alpha=5 \%)$. Partial results do not affect the fraudulent financial reporting, so the hypothesis was rejected in this study.

The results showed that the partial turnover of auditors (AUDCHANGE) did not affect fraudulent financial reporting because the logistic regression test results showed a coefficient value of -1.954 and a probability value (sig.) 0.206 where the value of sig. greater than $0.05(\alpha=5 \%)$. So in this study, the hypothesis was rejected. Meanwhile, the rationalization variable, which is proxied by the total accrual (TATA), shows the probability value (sig.) of 0.019 , where the sig value. greater than $0.05(\alpha=5 \%)$. However, the coefficient value is negative of $-59,226$, which means that the rationalization variable, which is proxied by total accruals (TATA), has a significant negative effect on financial reporting fraud that in this study, the hypothesis is rejected.

The results showed that partial Change of directors (DCHANGE) did not affect fraudulent financial reporting because the logistic regression test results showed a coefficient value of -0.840 and a probability value (sig.) of 0.595 value of sig. greater than $0.05(\alpha=5 \%)$. So in this study, the hypothesis was rejected. The results showed that partially the proportion of the number of independent commissioners (BDOUT) 
did not affect fraudulent financial reporting because the logistic regression test results showed a coefficient of -2.407 and a probability value (sig.) Of 0.740 , where the value of sig. greater than $0.05(\alpha=5 \%)$. So in this study, the hypothesis was rejected.

The results showed that partially the frequent number of CEO's pictures (CEOPIC) did not affect fraudulent financial reporting. The logistic regression test results showed a coefficient of 0.503 and a probability value (sig.) Of 0.279 , where the value of sig. greater than $0.05(\alpha=5 \%)$. So in this research, the hypothesis which states that the frequent number of CEO's picture has a positive influence is rejected. Meanwhile, the study results indicate that partially Family firms (DUAL) affect the fraudulent financial reporting because the logistic regression test results show a coefficient of 7.919 and a probability value (sig.) Of 0.024 , where the value of sig. smaller than $0.05(\alpha=5 \%)$. So in this study, the hypothesis was accepted.

\subsection{Discussion of Hypothesis Testing}

4.4.1. Effects of Pressure proxied by Financial Stability on Fraudulent Financial Reporting

The study results concluded that the pressure variable proxied by financial stability (ACHANGE) partially had a significant positive effect on fraudulent financial reporting. Companies with high asset growth ratios can be suspected of practicing fraudulent financial reporting because the high ratio of growth in assets indicates that the company has an unstable financial condition when viewed from the growth of its assets. A study conducted by Skousen et al. (2009) stated that the company would try to increase its assets by manipulating information on the growth of its assets. The company-owned assets can categorize the company's size, whether it is big or small (Apriliana \& Agustina, 2017). These conditions allow management to experience pressure to improve the unstable financial situation and allow management to commit fraudulent financial reporting. 
This study's results are in line with research conducted by Siddiq et al. (2017) and Wicaksana \& Suryandari (2019). They state that financial stability has a positive effect on fraudulent corporate financial reporting. However, the results of the study contradict the research conducted by Sasongko \& Wijayantika (2019), stated that financial stability does not affect financial reporting fraud because asset growth does not directly reflect the pressure factors that can make management commit fraud; this may be because the company's financial stability does not attract the attention of management to manipulate the ability to grow assets. However, this study concludes that manipulating asset growth can help the sample companies show good financial stability.

\subsubsection{Effects of Pressure proxied by External Pressure on Fraudulent Financial Reporting}

The study results concluded that the higher the leverage ratio of the company, the lower the level of financial reporting fraud. This can be caused by the higher level of corporate liability, the more stringent supervision conducted by creditors in providing loans considering the company's debt history. Also, suppose a company with a high leverage ratio manipulates its financial statements by reducing or hiding its debt balance. In that case, it will eventually result in the company becoming bankrupt. This study's results contradict the research of Tessa \& Harto (2016) and Tiffani (2015), which states that external pressure has a positive effect on financial reporting fraud.

\subsubsection{Effects of Opportunity proxied by Nature of Industry on Fraudulent Financial Reporting}

The study results concluded that the company did not necessarily manipulate its financial statements by reducing the receivable balance and or increasing the cash balance to get the ideal situation in the industry. Industrial conditions that require companies to show ideal conditions. The lower value of the ratio of accounts receivable shows no indication of fraudulent financial reporting through increased credit sales. However, this study's results state that management does not always manipulate 
accounts receivable balances to display good looking financial conditions. This study's results are in line with research conducted by Akbar (2017), stating that the nature of the industry does not affect fraudulent financial reporting. However, the study results contradict the research conducted by Damayani et al. (2017) and Muhandisah \& Anisykurlillah (2016). They stated that the nature of the industry has a positive effect on financial reporting fraud.

\subsubsection{Effects of Opportunity proxied by Effective Monitoring on Fraudulent Financial Reporting}

The results show that effective monitoring does not affect fraudulent financial reporting. This shows that the number of independent audit committee members does not affect fraud in financial reporting. This can be caused by the company's independent audit committee being a party from outside the company who has little knowledge of its business. Most likely, they have similar responsibilities to other companies, resulting in ineffective supervision, which allows committing fraud. This study's results are in line with research conducted by Yendrawati et al. (2019) and Akbar (2017), which states that the audit committee does not affect fraudulent financial reporting. However, the study results contradict the research of Ratmono et al. (2017), who states that the audit committee has a negative effect on fraudulent financial reporting.

\subsubsection{Effects of Rationalization proxied by Change of Auditor on Fraudulent}

\section{Financial Reporting}

The results of this study indicate that the presence or absence of auditor changes does not automatically indicate a fraudulent financial reporting. Change of auditors may be done not to reduce the possibility of detecting fraudulent financial reporting by previous auditors but as an effort to comply with point (1) Article 11 of Government Regulation of the Republic of Indonesia Number 20 the Year 2015 concerning Public Accountant Practices, which limits the period of service provided by a public accountant. This study's results are in line with research conducted by Bawakes et al. 
(2018) and Yesiariani \& Rahayu (2017), which states that the Change of auditor does not affect fraudulent financial reporting. However, the study results contradict the research of Saputra and Kesumanignrum (2015), which states that the Change of auditor has a positive effect on fraudulent financial reporting.

\subsubsection{Effects of Rationalization proxied by Total Accrual on Fraudulent Financial Reporting}

The study results concluded that the higher the company's total accrual ratio, the lower the level of financial reporting fraud. The results obtained are different from the hypotheses formulated, where total accruals have a positive effect on fraudulent financial reporting. The greater the ratio of total accruals indicates that the higher the likelihood of companies indicated committing fraud. This is because management is highly subjective, so that it is reflected in the company's accrual value. The subjective nature of management indicates that there is fraud in financial reporting. However, the study results concluded that subjective management judgments are good, which indicates that total discretionary accruals are smaller, while non-discretionary accrual rates are greater. The study results contradict the research of Murtanto \& Iqbal Muhammad (2016), which states that total accrual has a positive effect on fraudulent financial reporting.

4.4.7. Effects of Competence proxied by Change of Director on Fraudulent Financial Reporting

This study's results differ from the hypotheses that have been formulated, where changes in the composition of directors are positive for financial fraud. The more companies make changes to the board of directors, the higher the company's financial reduction. Changes in directors' composition may be made to replace the previous director with a new director who is more competent who can increase the effectiveness of the company's performance. This study's results are in line with the research of Annisya et al. (2016) and Apriliana \& Agustina (2017), which states that the Change of the board of directors does not influence fraudulent financial reporting. However, the 
study results contradict the research of Sasongko \& Wijayantika (2019), which states that the Change of auditor has a positive effect on fraudulent financial reporting.

\subsubsection{Effects of Competence proxied by Proportion of Independent Commissioner on} Fraudulent Financial Reporting

The results showed that partially the proportion of the number of independent commissioners (BDOUT) did not affect fraudulent financial reporting. This means that the number of the company's independent commissioners cannot minimize the practice of financial reporting fraud. It can be seen that the independent commissioner does not use the capabilities he has and does not perform a good oversight function of management so that an independent commissioner cannot control the possibility of fraudulent financial reporting practices by management. An independent board of commissioners composition in the company sample is sole to fulfill POJK regulation No. 33/POJK.04/2014 regarding directors and board of commissioners of listed companies or public companies and an effort to fulfill Good Corporate Governance. This study supports the results of research conducted by Akbar (2017), which states that the proportion of independent commissioners does not affect fraudulent financial reporting.

4.4.9. Effects of Arrogance proxied by Frequent Number of CEO's Picture on Fraudulent Financial Reporting

The arrogance of a CEO can be known through the number of CEO photos posted on the financial statements because a CEO will tend to display or show off the position he has (Triyanto, 2019). The results showed that partially the frequent number of CEO's pictures (CEOPIC) did not affect fraudulent financial reporting. This shows that the number of CEO photos displayed in the annual report cannot indicate fraud. The CEO photo displayed in the company's annual report aims to show the form of transparency of the activities carried out by the company responsible for the CEO and as proof of the CEO's participation. This study's results support the research conducted by Triyanto 
(2019) and Sasongko \& Wijayantika (2019), who stated that the frequent number of CEO's picture does not influence financial reporting fraud.

\subsubsection{Effects of Arrogance proxied by Family firms on Fraudulent Financial Reporting}

The results showed that partially family firms (DUAL) affected the fraudulent financial reporting. In the companies' sample, four companies were originally a family company and have now turned into a public company. Meanwhile, another research sample is a state-owned company that is a state-owned enterprise. The separation of positions between the board of directors and the board of commissioners and the two positions ensures no kinship. The kinship between a CEO and the board of commissioners can lead to fraudulent practices in financial reporting. This is because kinship makes a CEO given the power to negotiate with the board of commissioners, which allows a CEO to pursue his interests. The kinship between a CEO and the commissioners' board still often occurs because the company was originally a family company, which later developed and became a public company. In this study, there are cases where parents become chairman of the board of commissioners. Their children act as chair of the board of directors, so that management has the potential to make decisions freely and the lack of effectiveness of supervision conducted by a board of commissioners.

\section{Conclusion, Implication, and Limitation}

Based on the results of descriptive analysis and testing using logistic regression models carried out, it is concluded that fraud pentagon theory simultaneously affects fraudulent financial reporting. Partially, financial stability and family firms have a positive effect, external pressure and total accruals have a negative effect, and the nature of the industry, effective monitoring, changes in auditors, change in director, the proportion of independent commissioners, and frequent numbers of CEO's picture do not affect fraudulent financial reporting. 
This research implies that the fraud pentagon theory can detect fraudulent financial reporting because of the results of this study state that fraud pentagon theory has a simultaneous effect. Fraud pentagon theory can be used by auditors to indicate the existence of fraudulent financial reporting by taking into account the influential factors in this study, such as pressure factors measured using financial stability and external pressure ratios, rationalization factors with total accruals, and arrogance factors with family firms.

Practically, this research can be used as consideration for companies to pay attention to again that factors can trigger management to commit fraud. Companies need to pay attention to increase performance growth well without manipulating financial statements. Manipulating financial statements can bring the company into a state of bankruptcy because the things disclosed do not correspond to reality, so the company will not meet its liabilities. The stakeholders can also consider the results of this study before investing capital into the company by realizing prudence in investing. A go public company that was originally a family company in which the commissioner still has family relations with the company director is expected to supervise effectively and act in the best interest of the company and its stakeholders.

This study still has some limitations, including a research period that is still limited in 2014-2018. Some proxies have not been used in this study to measure the factors in the fraud pentagon theory. So that further research is expected to use different research samples such as companies listed on the Compass 100 Index, Sri-Kehati Index, and MNC 36 Index, companies subject to sanctions from the Financial Services Authority of Indonesia (OJK), financial sector companies, and other sectors listed on the Indonesian Stock Exchange by extending the research period. Use a combination of other proxies for fraud pentagon theory variables in detecting fraudulent financial reporting, for example, financial targets and personal financial need for pressure factors, external auditor quality for opportunity factors, audit opinions for rationalization factors, CEO's education, and CEO's tenure for capability factors, and political connections for the arrogance factor. 


\section{Reference}

Achmad, T., \& Pamungkas, I. D. (2018). Fraudulent Financial Reporting Based of Fraud Diamond Theory: A Study of the Banking Sector in Indonesia. JIAFE (Jurnal Ilmiah Akuntansi Fakultas Ekonomi), 4(2), 2372-2377.

Aghghaleh, S. F., Zakiah Muhammaddun Mohamed, \& Mohd Mohid Rahmat. (, 2016). Detecting financial statement frauds in Malaysia: Comparing the abilities of Beneish and Dechow Models. Asian Journal of Accounting and Governance, 7, 57-65.

Akbar, T. (2017). The Determination of Fraudulent Financial Reporting Causes by Using Pentagon Theory On Manufacturing Companies In Indonesia. International Journal of Business, Economics, and Law, 14(December), 106-113.

Albizri, A., Appelbaum, D., \& Rizzotto, N. (2019). Evaluation of financial statements fraud detection research: a multidisciplinary analysis. International Journal of Disclosure and Governance. Palgrave Macmillan UK. https://doi.org/10.1057/s41310-019-000679

Albrecht, C., Holland, D., Malagueño, R., Dolan, S., \& Tzafrir, S. (2015). The Role of Power in Financial Statement Fraud Schemes. Journal of Business Ethics, 131(4), 803-813. https://doi.org/10.1007/s10551-013-2019-1

Annisya, M., Lindrianasari, \& Asmaranti, Y. (2016). Pendeteksian Kecurangan Laporan Keuangan Menggunakan Fraud Diamond. Jurnal Bisnis Dan Ekonomi, 23(1), 72-89.

Aprilia, A. (2017). Analisis Pengaruh Fraud Pentagon Terhadap Kecurangan Laporan Keuangan Menggunakan Beneish Model Pada Perusahaan Yang Menerapkan Asean Corporate Governance Scorecard. Jurnal ASET (Akuntansi Riset), 9(1), 101. https://doi.org/10.17509/jaset.v9i1.5259

Apriliana, S., \& Agustina, L. (2017). The Analysis of Fraudulent Financial Reporting Determinant through Fraud Pentagon Approach. Jurnal Dinamika Akuntansi, 9(2), 154-165. https://doi.org/10.15294/jda.v7i1.4036

Bawakes, H. F., Simanjuntak, A. M. ., \& Daat, S. C. (2018). Pengujian Teori Fraud Pentagon Terhadap Fraudulent Financial Reporting. Jurnal Akuntansi \& Keuangan Daerah, 13(1), 114-134.

Chi, C. W., Hung, K., Cheng, H. W., \& Tien Lieu, P. (2015). Family firms and earnings management in Taiwan: Influence of corporate governance. International Review of Economics and Finance, 36, 88-98. https://doi.org/10.1016/j.iref.2014.11.009

Dahya, J., \& McConnell, J. J. (2005). Outside directors and corporate board decisions. Journal of Corporate Finance, 11(1-2), 37-60. https://doi.org/10.1016/j.jcorpfin.2003.10.001

Damayani, F., Wahyudi, T., \& Yuniartie, E. (2017). Pengaruh Fraud Pentagon Terhadap Kecurangan Laporan Keuangan Pada Perusahaan Infrastruktur Yang terdaftar Di Bursa Efek Indonesiatahun 2014 - 2016. AKUNTABILITAS: Jurnal Penelitian Dan 
Pengembangan Akuntansi, 11(2), 151-170. https://doi.org/10.29259/ja.v11i2.8936

Dechow, P. M., Hutton, A. P., Kim, J. H., \& Sloan, R. G. (2012). Detecting Earnings Management: A New Approach. Journal of Accounting Research, 50(2), 275-334. https://doi.org/10.1111/j.1475-679X.2012.00449.x

Examiners, A. of C. F. (2018). Report To The Nation 2018 Global Study on Occupational Fraud and Abuse. Retrieved from https://www.acfe.com/report-to-thenations/2018/default.aspx

Gupta, C. M., \& Kumar, D. (2020). Forensic Accounting A Tool To Curb Financial Crimes Chander Mohan Gupta 1 Dr. Devesh Kumar 2, 173229(56), 990-998

Hery. (2016). Analisis Laporan Keuangan. Jakarta: PT Gramedia WidiaSarana Indonesia.

Horwath, C. (2012). The Mind Behind The Fraudsters Crime: Key Behavioral and Environmental Elements. Crowe Horwath LLP, 1-62. Retrieved from www.crowe.com

Hugo, J. (2019). Efektivitas Model Beneish M-Score Dan Model F-Score Dalam Mendeteksi Kecurangan Laporan Keuangan. Jurnal Muara Ilmu Ekonomi Dan Bisnis, 3(1), 165. https://doi.org/10.24912/jmieb.v3i1.2296

Hussain Alkdai, H. K., \& Hanefah, M. M. (2012). Audit committee characteristics and earnings management in Malaysian Shariah-compliant companies. Business \& Management Review, 2(2), 52-61. Retrieved from http://search.ebscohost.com/login.aspx?direct=true \&db=bth\&AN=78392157\&site $=$ eh ost-live \&scope=site

Indarto, S. L., \& Ghozali, I. (2016). Fraud diamond: Detection analysis on fraudulent financial reporting. Risk Governance and Control: Financial Markets and Institutions, 6(4Continued1), 116-123. https://doi.org/10.22495/rcgv6i4c1art1

Matoussi, H., \& Gharbi, I. (2011). Board Independence and Corporate Fraud: The case of Tunisian firms. Economic Research Forum, 1-27.

Muhandisah, Z., \& Anisykurlillah, I. (2016). Predictive Analysis of Financial Statement Fraud with Fraud Triangle Perspective. AAJ: Accounting Analysis Journal, 5(4), 381-388. https://doi.org/ISSN 2252-6765

Murtanto \& Iqbal Muhammad. (2016). Analisa Pengaruh Faktor-Faktor Fraud Triangle Terhadap Kecurangan Laporan Keuangan Pada Perusahaan Property Dan Real Estate yang Terdaftar Di Bursa Efek Indonesia. Seminar Nasional Cendekiawan 2016, (2002), $1-20$.

N, C., Z, B. Y., \& W, A. (2019). Analysis of Fraud Triangle, Fraud Diamond, and Fraud Pentagon Theory to Detecting Corporate Fraud in Indonesia, 3(4), 73-78.

Puspasari, N. (2015). Fraud Theory Evolution and Its Relevance To Fraud Prevention in the Village Government in Indonesia*. Asia Pacific Fraud Journal, 1(2), 177. 
https://doi.org/10.21532/apfj.001.16.01.02.15

Ratmono, D., Diany, Y. A., \& Puwanto, A. (2017). Dapatkah Teori Fraud Triangle Menjelaskan Kecurangan Dalam Laporan Keuangan? Jurnal Akuntansi Dan Auditing, Volume 14/.

Saputra, M. A. R., \& Kesumanignrum, N. D. (2015). Analisis Faktor - Faktor Yang Mempengaruhi Fraudulent Financial Reporting Dengan Perspektif Fraud Pentagon Pada Perusahaan Perbankan Yang Terdaftar Di Bursa Efek Indonesia Tahun 2011-2015. Jurnal Akuntansi Dan Keuangan, Vol. 22 No.

Sasongko, N., \& Wijayantika, S. F. (2019). Faktor Resiko Fraud Terhadap Pelaksanaan Fraudulent Financial Reporting (Berdasarkan Pendekatan Crown'S Fraud Pentagon Theory). Riset Akuntansi Dan Keuangan Indonesia, 4(1), 67-76. https://doi.org/10.23917/reaksi.v4i1.7809

Siddiq, F. R., Achyani, F., \& Zulfikar. (2017). Fraud Pentagon Dalam Mendeteksi Financial Statement. Seminar Nasional Dan The 4th Call for Syariah Paper, 1-14. Retrieved from http://hdl.handle.net/11617/9210

Skousen, C. J., Smith, K. R., \& Wright, C. J. (2009). Detecting and Predicting Financial Statement Fraud: The Effectiveness of The Fraud Triangle and SAS No. 99 in Corporate Governance and Firm Performance. International Journal of Quality \& Reliability Management (Vol. 32). https://doi.org/10.1108/S1569-3732(2011)0000014001

Stice, J. D. (1991). Using Financial and Market Information to Identify Pre-Engagement Factors Associated with Lawsuits against Auditors. The Accounting Review, 66(3), 516-533. https://doi.org/DOI:

Tessa, C. G., \& Harto, P. (2016). Fraudulent Financial Reporting: Pengujian Teori Fraud Pentagon Pada Sektor Keuangan dan Perbankan di Indonesia (Fraudulent Financial Reporting: The Testing of Pentagon Fraud Theory in Financial and Banking Companies Sector in Indonesia). Simposium Nasional Akuntansi XIX, 1-21.

Tiffani, L. dan M. (2015). Deteksi Financial Statement Fraud dengan Analisis Fraud Triangel pada Perusahaan Manufaktur yang Terdaftar Di Bursa Efek Indonesia. Jurnal Akuntansi Dan Auditing Indonesia, 19, 112-125.

Triyanto, D. N. (2019). Fraudulence Financial Statements Analysis using Pentagon Fraud Approach. Journal of Accounting Auditing and Business, 2(2), 26. https://doi.org/10.24198/jaab.v2i2.22641

Umarsono. (2016). Efektivitas Fraud Triangle dalam Mendeteksi Manajemen Laba Akrual Berbasis SAS NO . 99 pada Perusahaan Penanaman Modal Asing. Jurnal Riset Akuntansi Dan Perpajakan, 3(2).

Wicaksana, E. A., \& Suryandari, D. (2019). Pendeteksian kecurangan laporan keuangan pada perusahaan pertambangan di bursa efek indonesia. Journal of Accounting and Management Information Systems, 4(1), 44-59. 
Yendrawati, R., Aulia, H., \& Prabowo, H. Y. (2019). Detecting the Likelihood of Fraudulent Financial Reporting: an Analysis of Fraud Diamond. Asia-Pacific Management Accounting Journal, 14(1), 43-69.

Yesiariani, M., \& Rahayu, I. (2017). Deteksi financial statement fraud: Pengujian dengan fraud diamond. Jurnal Akuntansi \& Auditing Indonesia, 21(1), 49-60. https://doi.org/10.20885/jaai.vol21.iss1.art5

Yusof, M. K., Khair, A., \& Simon, J. (2015). The Macro theme Review A multidisciplinary journal of global macro trends Fraudulent Financial Reporting: An Application of Fraud Models to Malaysian Public Listed Companies. The Macro theme Review, 4(3), 126145 . 
The Indonesian Journal of Accounting Research - Sept, Vol. 23 , No.3 , 2020

\section{intentionally blank}

